\title{
The FDA is no place for politics
}

F or 100 years, the US Food and Drug Administration (FDA) has been responsible for protecting and promoting the health of the public, assuring that foods are safe and that drugs, vaccines and medical devices are safe and effective. It also provides the public with accurate information so that they can make informed choices about medicines they use and food they eat. Finally, the FDA helps speed innovations that make medicines more effective, safer and more affordable.

The FDA has been without a permanent commissioner for much of the Bush presidency. Given that the FDA oversees products whose sales constitute about a quarter of the US economy, it is no wonder that nominees for commissioner are scrutinized intensely by interest groups and Congress alike. Add to this the fact that President Bush's nominee, Dr. Andrew C. von Eschenbach, is controversial, and it is almost certain that this agency will not have a Senate-confirmed commissioner any time soon. This will probably diminish the reputation and the effectiveness of this crucial agency. The health and safety of the American public should not be left in such a precarious position.

On 15 March 2006, President Bush nominated the acting commissioner of the FDA, von Eschenbach, to become permanent head of the agency. von Eschenbach was appointed acting commissioner of the FDA in September 2005, when then-commissioner Lester Crawford abruptly resigned. von Eschenbach is a Bush family friend from Texas who spent 25 years at the University of Texas's M.D. Anderson Cancer Center, before being appointed director of the National Cancer Institute in 2002.

As a cancer expert, he's uniquely qualified to head the FDA, says Margaret Foti, who heads the American Association for Cancer Research. But Sidney M. Wolfe, director of Public Citizen's Health Research Group, disagrees, describing von Eschenbach as "yet another Bush appointee whose main reason for being selected is that he is a family friend, someone who has been warmly embraced by the regulated industriesespecially the pharmaceutical industry - and someone who has been and will continue to be loyal to the White House agenda".

von Eschenbach's nomination has stirred up opposition over an issue far removed from his qualifications to run the agency: the 'morning-after' emergency contraceptive pill 'Plan B'. Antiabortion groups oppose making this pill available without a doctor's prescription, whereas health advocates support it. Supporters of the application, including Democratic Senators Patty Murray and Hillary Rodham Clinton, have vowed to block von Eschenbach's nomination until the FDA makes a decision on Plan B.

The fight over Plan B has been fierce. The FDA has repeatedly rejected the advice of its scientific advisors and its own staff and denied the application, which has been pending for three years. Susan F. Wood, who was the director of the agency's Office of Women's Health at the time, quit in protest of what she said was political interference in the agency's scientific deliberations. Likewise, Frank Davidoff, the editor emeritus of the Annals of Internal Medicine and consultant to one of the committees that voted to approve the application, said that the agency was clearly placing the pursuit of its moral agenda over the facts.

At this point, it is unclear whether von Eschenbach will follow in the footsteps of his predecessors, or whether he will let the science and the scientists guide FDA policy and decisions. If he follows the lead of the Bush administration and its allies, he will not do anything that would anger them-as approval of Plan B would.

Plan B is not the only socially and politically charged issue that the new FDA commissioner will have to rule on. A new vaccine against cervical cancer is also causing clashes between health advocates and social conservatives.

The FDA is currently conducting a priority review of Merck's investigational human papilloma virus (HPV) vaccine, and should announce its licensing decision by June 8. Although many strains of HPV are innocuous, some can cause cancerous lesions of the cervix, making them the primary cause of cervical cancer. Cervical cancer is the 11th most prevalent cancer among US women, with over 10,000 new cases and more than 3,700 deaths in 2005. What is most remarkable about the vaccine is that it seems to have no serious side effects and it has close to $100 \%$ efficacy. Another vaccine, which is being developed by GlaxcoSmithKline, looks equally promising. Because HPV is sexually transmitted, the vaccine must be given to people before they are exposed to the virus through sexual activity.

In the US, both Plan B and the HPV vaccine have social and religious conservatives in an uproar. They believe that widespread use of the HPV vaccine or availability of Plan B will encourage promiscuity in adolescents. In fact, the Bush administration, its allies on Capital Hill and the religious base of the Republican Party prefer to rely on education programs that promote abstinence from sexual activity.

There is little doubt that the same groups that oppose Plan B and the HPV vaccine would feel similarly about an HIV vaccine, should one become available. David Baltimore, president of the California Institute of Technology for the past eight years, has said, “...this is religious zealotry masked as politics, and it runs against everything that I as a scientist believe in, that I have devoted my life to. We are talking about basic public health now. What moral precepts allow us to think that the risk of death is a price worth paying to encourage abstinence as the only approach to sex?" (M. Specter, The New Yorker 13 March 2006).

We count on the FDA to reliably assess the safety and effectiveness of our medicines, vaccines and medical devices, for the safety of the blood and food supply and to provide accurate science-based information. The FDA needs a permanent commissioner whose main interest is in public health and welfare, and who can make independent decisions on the basis of scientific evidence. This is what the public deserves. 